\title{
Laser welding of austenitic ferrofluid container for the KRAKsat satellite
}

\author{
Rafał Janiczak $^{1} \cdot$ Krzysztof Pańcikiewicz $^{1}$ \\ Received: 4 November 2020 / Accepted: 25 February 2021 / Published online: 12 March 2021 \\ (C) The Author(s) 2021
}

\begin{abstract}
The production of a ferrofluid container, intended for use in the KRAKsat (CubeSat type) satellite in space conditions, is presented. Mechanized laser beam welding for AISI 316L stainless steel test joint and container prototype was developed and tested. The welded test joints were examined by non-destructive visual, penetration and radiographic testing and destructive testing by macro- and microscopic examination, static tensile test, static bending test, and hardness measurements. The welded container prototype was examined by leak test, temperature-vacuum test and vibration test. Test joints' evaluation showed a proper selection of welding parameters and expected quality of joints. Austenitic microstructure with small $\delta$-ferrite content in base materials, heat-affected zones, and welds guarantees sufficient mechanical properties for this part geometry. The tensile strength range of test joints was $687-729 \mathrm{MPa}$, hardness range was 140-200 HV3, and the bending angle was $180^{\circ}$. Welding of the prototype container and testing of tightness, resistance to temperature changes, and vibration were successful. Compliance with flywheel design and manufacturing requirements will enable the launch of a research satellite into orbit with such a wheel.
\end{abstract}

Keywords Ferrofluid $\cdot$ KRAKSat $\cdot$ CubeSat $\cdot$ Satellite $\cdot$ Laser beam welding

\section{Introduction}

Maintaining a stable orientation of space vehicles in longterm space missions or changing the orientation of the vehicle depending on the needs requires the use of torque generating parts which are able to rotate the vehicle according to its axis of rotation. Many satellite missions use gravity gradient stabilization or just a magnetic control technique to control the position of the satellite. These methods have been used because they are inherently simple and require minimal cost [1]. Currently used reaction wheels for the rotation of space vehicles according to their axis have a mechanical effect, which causes many inconveniences. Mechanical reaction wheels are heavy and complex, require additional bearings and lubrication, are unreliable, and wear out quickly [2-4]. A new solution that eliminates the disadvantages of traditional reaction wheels is a liquid reaction

Recommended for publication by Commission XI - Pressure Vessels, Boilers, and Pipelines

Krzysztof Pańcikiewicz

krzysztof.pancikiewicz@agh.edu.pl

1 AGH University of Science and Technology, al. Mickiewicza 30, 30-059 Krakow, Poland wheel that does not have a single movable part that can catch or jam. Torque is generated by the flow of a ferrofluid liquid in a special torus-shaped container. Recently, small satellites weighing 50 to $100 \mathrm{~kg}$ have been developed. The number of potential users of small and drastically cheap satellites is growing worldwide. Therefore, miniaturization of all components on board the satellite is desirable. Reaction wheels for position control on satellites are an important key technology and difficult to miniaturize due to the special nature of their function [5].

This article presents the manufacturing technologies and testing of the ferrofluid container that was used to build small flywheels for KRAKsat satellite [6]. Special requirements for objects used in space [7] include no adverse effect on the planned experiment. There are also economic aspects. Requirements for the ferrofluid container:

- Magnetic indifference - the container used in the experiment should be made of a magnetically inert material so as not to deform the magnetic field created by the electromagnets.

- Resistance to elevated temperatures - the material and welded joint should retain their properties up to $110^{\circ} \mathrm{C}$. This is the maximum temperature that can be inside the satellite. 
- Resistance to low temperatures - the container material should maintain its design properties at temperatures down to $-170^{\circ} \mathrm{C}$. It should not be brittle at low temperatures.

- Adequate strength - it is important that the material from which the container will be made has the strength to counteract the forces resulting from the pressure difference between the medium in the container and the vacuum of space. In addition, due to the difference in temperature, thermal expansion of the liquid occurs. Since the coefficients of thermal expansion for liquids are much higher than for solids at high temperatures, an additional pressure is created pushing the walls of the container.

- Shock resistance-during the launch of a space rocket, random vibrations and strong overloads occur that the structure must cope with.

- Light weight - carrying $1 \mathrm{~kg}$ of cargo into space costs from $\$ 10,000$ to $\$ 25,000$. Therefore, it is advisable to use materials of the lowest possible weight for all construction elements.

- Good machinability - the container has a specific shape and surface quality that can only be achieved by machining. The material from which the container will be made should have good machinability and be able to give it exact dimensions.

- Good weldability - container technology requires the connection of parts. The choice of material and joining technology requires attention to its ability to form durable joints. Connections should show high strength and tightness. They must also not have other defects that could lead to leakage or failure of the component.

These conditions are met by various engineering materials; however, taking into account the economic aspect in the lowbudget project, austenitic steels are the first choice. Unfortunately, the main problem is thermal expansion and the cellular structure of the weld, leading to hot cracking [8, 9]. Ogura et al. [8] and Bansod and Patil [10] have shown a small amount of $\delta$-ferrite in austenitic steel provide resistance to hot cracking. Weldability depends not only on the properties of the materials but also on the joint design and manufacturing technology, including the welding method. One of the heat sources is laser, which is now widely used for welding and material processing [11-14] and can potentially be used to weld a container. Steels with BCC [15-17] and FCC [18-20] crystallographic space groups, aluminum alloys [21], titanium alloys [22], nickel alloys [23], plastics [24], and composites [25] can be laser beam welded. These joints are characterized by a narrow weld and a heat-affected zone with mechanical properties similar to those of joints made with conventional electric arc processes [26] and often exceeding them. The small volume of the weld causes relatively less shrinkage, which significantly reduces the strain. Another advantage is also the possibility of increasing the welding speed compared to other conventional processes, but solidification cracking occurs easily at a high welding speed. Bakir et al. [27] and Kadoi et al. [9] demonstrated an on-line/in situ monitoring system of the susceptibility to hot cracking during welding, applicable to laser beam welding. It is possible to make both longitudinal and circumferential joints ensuring the tightness of the joint [28], which is needed at the container. In special cases, two sources are combined to take advantage of their advantages, creating hybrid laser-arc welding [29-31].

\section{Materials and methods}

Based on the set requirements [7], austenitic stainless steel AISI 316L (X2CrNiMo17-12-2, 1.4404) steel was selected. Chemical composition and mechanical properties is presented in Table 1. Fast cooling of welds (possible in the LBW method) is a positive phenomenon because these welds have microstructures with metastable and stable phases, with minimal segregation and fine grains, which improve mechanical properties and the stresses occurring in the welded material are reduced [32]. The density of $\sim 8 \mathrm{~kg} / \mathrm{dm}^{3}$ makes it the heaviest material used in the construction of the KRAKsat satellite. This is a factor against the material. However, the remaining properties, especially good static and dynamic mechanical properties and lack of adverse magnetic properties, are in favor of this steel, compensating for the disadvantage of a

Table 1 Chemical composition and selected mechanical properties of AISI 316L steel acc. to ASTM A240-20a

\begin{tabular}{|c|c|c|c|c|c|c|c|c|c|}
\hline \multicolumn{10}{|c|}{ Chemical composition } \\
\hline Element & $\mathrm{C} \max$ & Mn $\max$ & $\mathrm{P} \max$ & $\mathrm{S} \max$ & Si max & $\mathrm{Cr}$ & $\mathrm{Ni}$ & Mo & $\mathrm{N} \max$ \\
\hline wt. $\%$ & 0.030 & 2.00 & 0.045 & 0.030 & 0.75 & $16.0-18.0$ & $10.0-14.0$ & $2.00-3.00$ & 0.10 \\
\hline \multicolumn{10}{|c|}{ Mechanical properties } \\
\hline \multicolumn{2}{|c|}{$\begin{array}{l}\text { Tensile strength, min, } \mathrm{MPa} \\
485\end{array}$} & \multicolumn{2}{|c|}{ Yield strength, min, MPa } & \multicolumn{2}{|c|}{ Elongation in $50 \mathrm{~mm}, \mathrm{~min}, \%$} & \multicolumn{2}{|c|}{ Brinell hardness, max } & \multicolumn{2}{|c|}{ Rockwell B hardness, max } \\
\hline
\end{tabular}


Fig. 1 Joint details. a Joint design. b Welding sequence

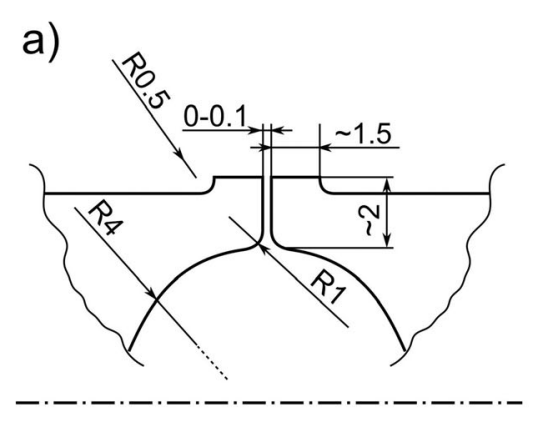

b)

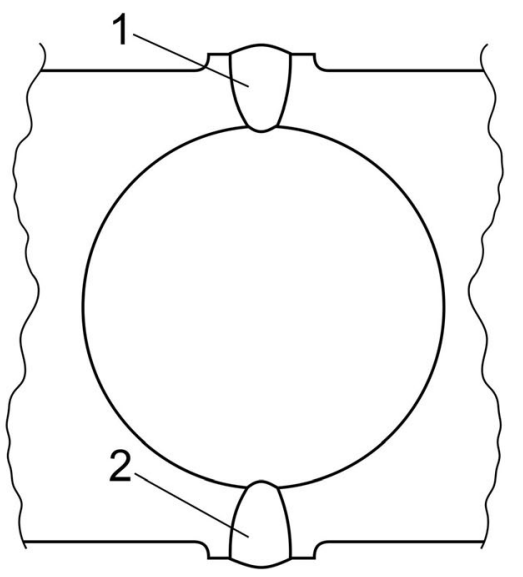

relatively large mass of material [33-35]. The steel also has excellent weldability and good machinability which is important information in the context of the production process [36]. To produce a container capable of containing a ferrofluid in cosmic vacuum, laser beam welding was used, because it provides the most concentrated heat source for welding with high welding accuracy, high-quality welds, and less deformation [37].

To determine the appropriate parameters of the laser beam, eight AISI 316L steel samples were prepared, which, when assembled, formed four test joints. The sample consisted of two opposite butt welds made with full penetration. It was possible to make two 100-mm-long welds on each sample. The cross section of the samples reflected the cross section of the target container in a one to one ratio.

The welds were made using 521-TruLaser Cell 7040 Fiber radiation sources. Welding was carried out without the addition of a filler material. The material filling the groove was contained in a convex strip protruding above the flat surfaces of the welded parts. Two single-stitched marginal welds with folded edges were completely melted. The weld length was $100 \mathrm{~mm}$, the weld thickness (S) was $2 \mathrm{~mm}$, the maximum gap before welding, and the tolerance dimension resulting from the machining process (b) was $0.1 \mathrm{~mm}$ (Fig. 1a). Two beads were made (Fig. 1b). Shielding gas Argon 99.99\% (I1 according to ISO 14175) was used with flow rate $20 \mathrm{l} / \mathrm{min}$ and backing $12 \mathrm{l} / \mathrm{min}$. Preheating and heat treatment after welding were not used.

Due to the high requirements for the quality of welds, their small dimensions, and the requirement for very accurate welding operations, samples specially prepared for this purpose with the container cross section were laser beam welded, being placed relative to each other according to Fig. 2 . The beam parameters at which the weld had the best quality during examination were used to weld the prototype.

Table 2 records the optimal welding parameters for the test joint, which was then tested.

The test joint and prototype container were examined by nondestructive visual, penetration, and radiographic tests. Visual testing (acc. to ISO 17637 and EN 13018) was made by direct method in intense lighting $~ 580 \mathrm{~lx}$ with universal welding gauge with resolution $0.05 \mathrm{~mm}$. Liquid penetrant inspection (acc. to ISO 3452-1) was carried out on a 2-mmthick plate cut from the test joint with colored penetrant with kit IIIC(2)e and light intense 580 lx. Acceptance level was level " $2 \mathrm{x}$ " (highest) acc. to ISO 23277. Penetration time was $30 \mathrm{~min}$ and development time $30 \mathrm{~min}$. Test temperature measured with N8-303 ETI Ltd. pyrometer was $21^{\circ} \mathrm{C}$. Radiographic test (acc. to ISO 17636-1) was carried out on a 2-mm-thick plate cut from the test joint in class B using X-ray
Fig. 2 Preparation of the parts for welding
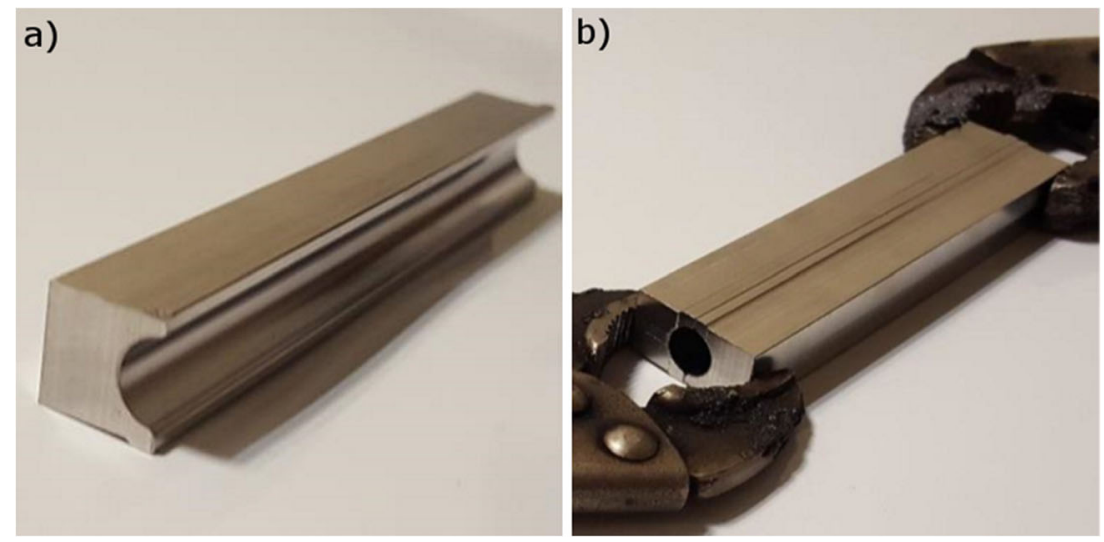
Table 2 Process parameters of LBW

\begin{tabular}{llllll}
\hline Run & Power, W & Focus, mm & Frequency, HZ & Travel speed, m/min & Head angle, ${ }^{\circ}$ \\
\hline 1 & $2300-2700$ & $4.8-5.2$ & $4700-5300$ & $1.9-2.1$ & 1.5 \\
2 & $2500-2700$ & $8-10$ & $4700-5300$ & $1.4-1.6$ & 1.5 \\
\hline
\end{tabular}

lamp with voltage $100 \mathrm{kV}$ and current $5 \mathrm{~mA}$. For x-raying elliptical method was used (pos. 11 acc. to ISO 17636-1) in two exposures shifted relative to each other by $90^{\circ}$. The image was registered on Fujifilm IX100 film. The exposure time was $1 \mathrm{~min}$, and the required image quality is W 16. Acceptance level was level " 1 ” (highest) acc. to ISO 10675-1.

The test joint was examined by destructive macroscopic and microscopic tests, static tensile test, static bending test, and hardness measurements. The static tensile test was carried out on two samples with a square cross section with a side length of $2 \mathrm{~mm}$ and a sample length of $12 \mathrm{~mm}$. The ambient temperature during the test was $22.9^{\circ} \mathrm{C}$, while the sample temperature was $22.5^{\circ} \mathrm{C}$. The tensile test was carried out on a ZD20 testing machine. The static bending test was carried out on two samples with dimensions $t_{\mathrm{s}}=2 \mathrm{~mm}$ and $b=8$ $\mathrm{mm}$. The distance between the support rollers was $L=14.5$ $\mathrm{mm}$, diameter of the bending mandrel $d=\varnothing 8 \mathrm{~mm}$. The test was carried out at an ambient temperature of $22.9^{\circ} \mathrm{C}$ with a sample temperature of $22.5^{\circ} \mathrm{C}$. The sample for light metallographic examination was cut in a plane perpendicular to the welding direction, then ground on sandpaper in sequence: 800,1000 , and 2000, polished with aluminum oxide suspension $\left(\mathrm{Al}_{2} \mathrm{O}_{3}\right)$, and electrolytically in $10 \%$ aqueous $\mathrm{CrO}_{3}$ solution. A detailed analysis of the weld microstructure was carried out using Phenom XL scanning electron microscopy with EDS analysis for chemical composition. Hardness measurements were performed by the Vickers method $(29.61 \mathrm{~N})$ with use Zwick/Roell ZHU 187.5 universal hardness tester. The distance between the indentations was $0.6 \mathrm{~mm}$.

The container prototype was leak, temperature-vacuum and vibration tested. The leak test was the immersion bubble test in which the container at $0.8 \mathrm{MPa}$ pressure is completely immersed in the test liquid (water). The resulting streams of bubbles reveal leaks. Temperature-vacuum test was carried

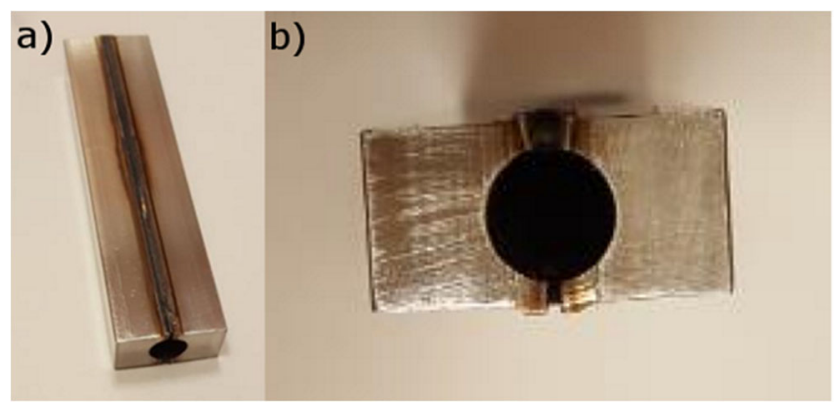

Fig. 3 General view of test joints out in a vacuum oven. The container temperature was raised to $80^{\circ} \mathrm{C}$ three times and lowered three times to $-50^{\circ} \mathrm{C}$ at $10^{-3}$ $\mathrm{Pa}$ vacuum. Vibration test was carried out on a laboratory shaker with maximum vibration level of $0.61 \mathrm{~g}^{2} / \mathrm{Hz}$.

\section{Results and discussion}

\subsection{Examination of test joints}

General view of test joints is presented in Fig. 3. The welds were $2 \mathrm{~mm}$ thick and $100 \mathrm{~mm}$ long. Welded joints were at B quality level (acc. to EN ISO 13919-1) in visual testing (VT), penetration testing (PT), and radiographic testing (RT). Pores, cracks, and other welding imperfections were not observed.

Macroscopic tests were performed on cross sections of the welded joints (Fig. 4). The width of the second weld in half thickness is twice as large as that of the first weld, which is caused by a relatively lower welding speed and a larger focus (Table 2). The observed weld profile corresponds to the model proposed by Kik [38].

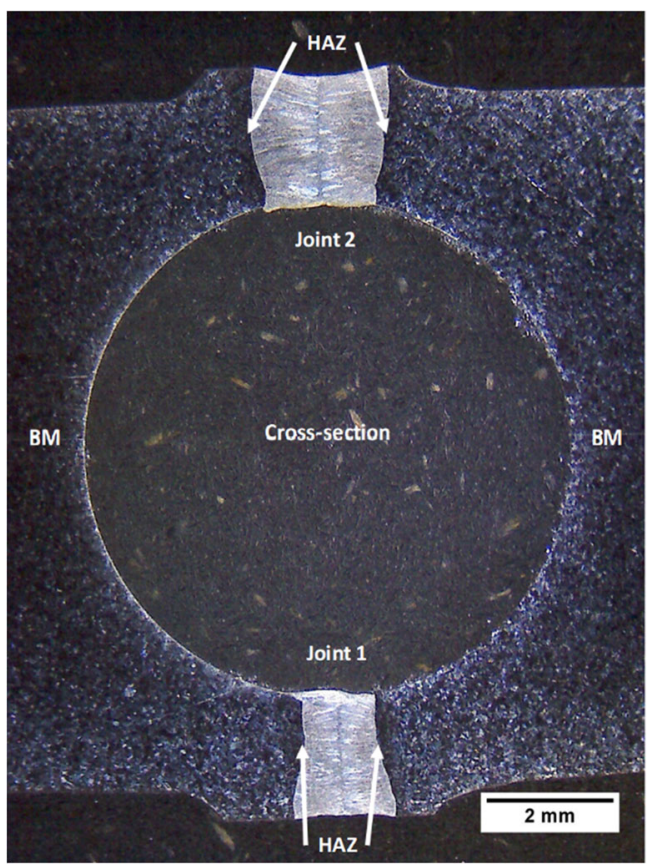

Fig. 4 Macrostructure of the tested sample: HAZ, heat-affected zone, $\mathrm{BM}$, base material 
Fig. 5 Microstructure in the area of weld 1 . a General view of the joint. b View in the area of transition of the weld into the heat-affected zone and base material
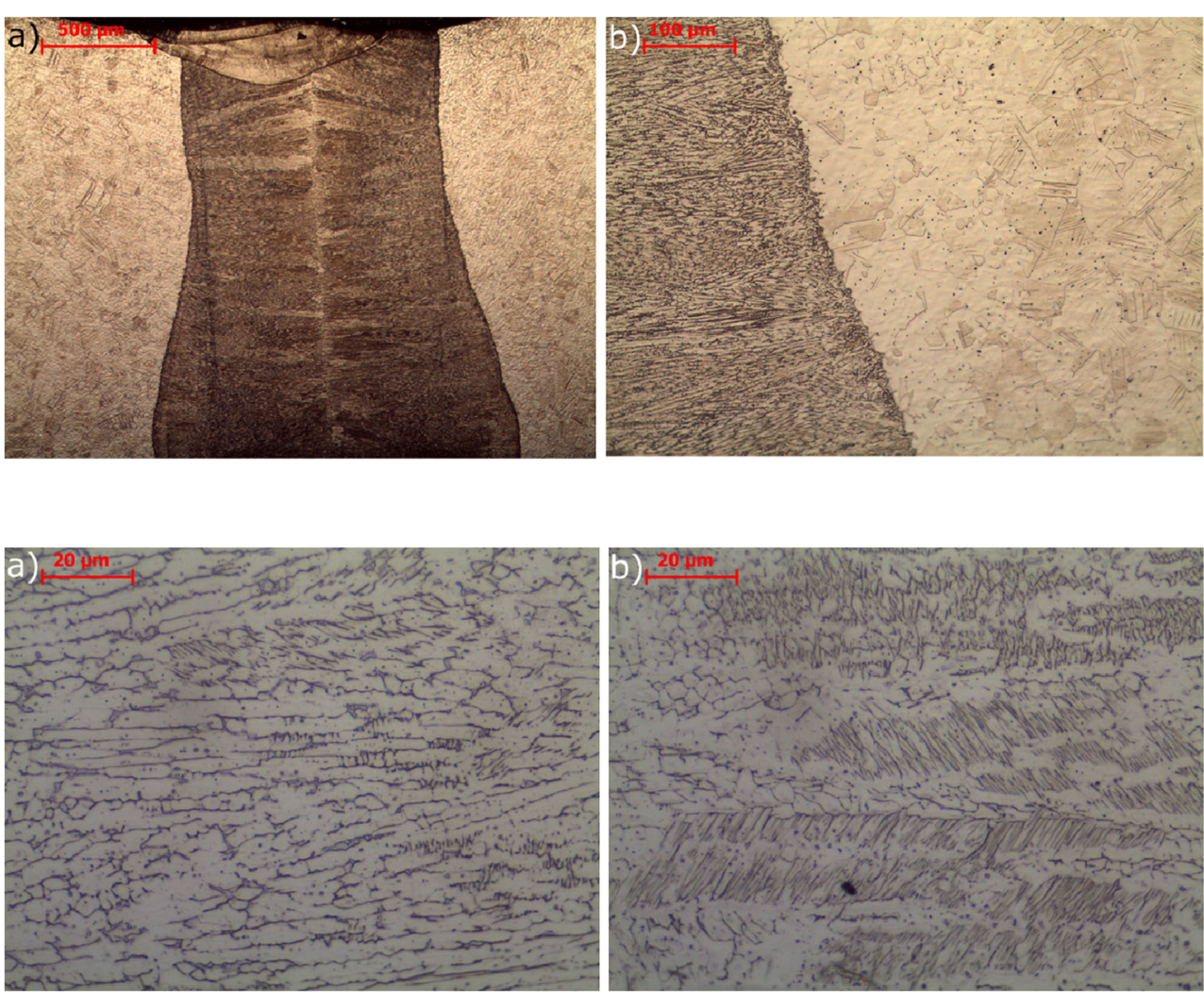

Fig. 6 Area of column crystals in the weld 1. a Austenite with lamellar ferrite. b Austenite with mixture of lamellar and mesh ferrite
Clearly marked fusion lines and weld axes are visible. No obvious imperfections were detected. The root of both welds did not significantly affect the cross-section of the container, so there was no significant reduction in its volume. Microstructure of welded joint is presented in Fig. 5.

The microstructure of the base material in the weld area 1 is shown in Fig. 5b (to the right). Observations showed the presence of equiaxed, twin-crystal structure austenite grains with locally visible slip-bands, described, e.g., by Hernández-Trujillo et al. [39] and Pańcikiewicz et al. [40]. The very small heataffected zone is characteristic for laser beam welding. Crystallization of liquid metal occurred through very fast heat flow to the base material, as a result the weld area that crystallized at the end is in the axis of weld (Fig. 5a). These effects are consistent with the observations of Kadoi [40]. In the heat affected zone, unlike the base material, no slip-bands are observed, and the number of twin-crystals is much smaller. There was no clear grain growth (Fig. 5b). The weld is characterized by both cellular and locally dendritic-cellular structure, which is the reason for the change in ferrite- $\delta$ morphology, as also observed by, e.g., Tokita et al. [41] and Hochanadel et al. [42]. In the weld, the columnar crystal area is seen to be separated (Fig. 6) with lamellar (Fig. 6a) ferrite and a mixture of lamellar and mesh ferrite (Fig. 6b) and the area of equiaxed crystals in the weld axis (Fig. 7), described by, e.g., Moteshakker and Danaee [43] and Chen et al. [44].

Microscopic observations revealed an area at the root of the weld that had been melted down during the second, opposite welding (Fig. 8). In the area of the fusion line, epitaxial growth is visible, consisting of crystallization of crystals from the previously laid layer with the same orientation as the previous bead, described, e.g., by Tokita et al. [41] and Tuz [45]. The microstructures observed in the area of the second weld, shown in Fig. 9, are analogous to those in the first weld (except for the remelted area).

In the matrix area (Fig. 10a), higher nickel and manganese content was identified than in the cell boundary areas (Fig. 10b). Higher content of chromium, molybdenum, and silicon

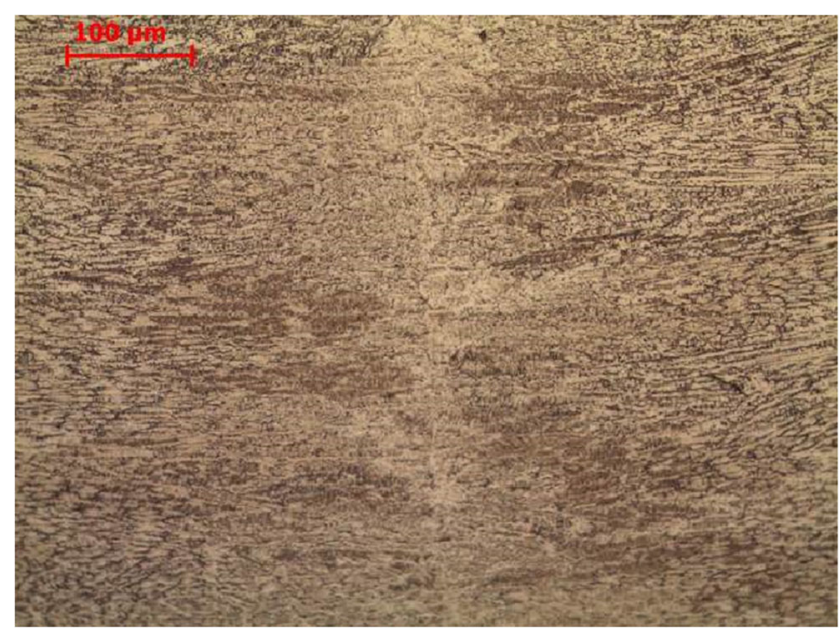

Fig. 7 Area of equiaxed crystals in the axis of weld 1 
Fig. 8 Re-melted weld area 1. a General view. b Detail viewaustenite with lamellar ferrite
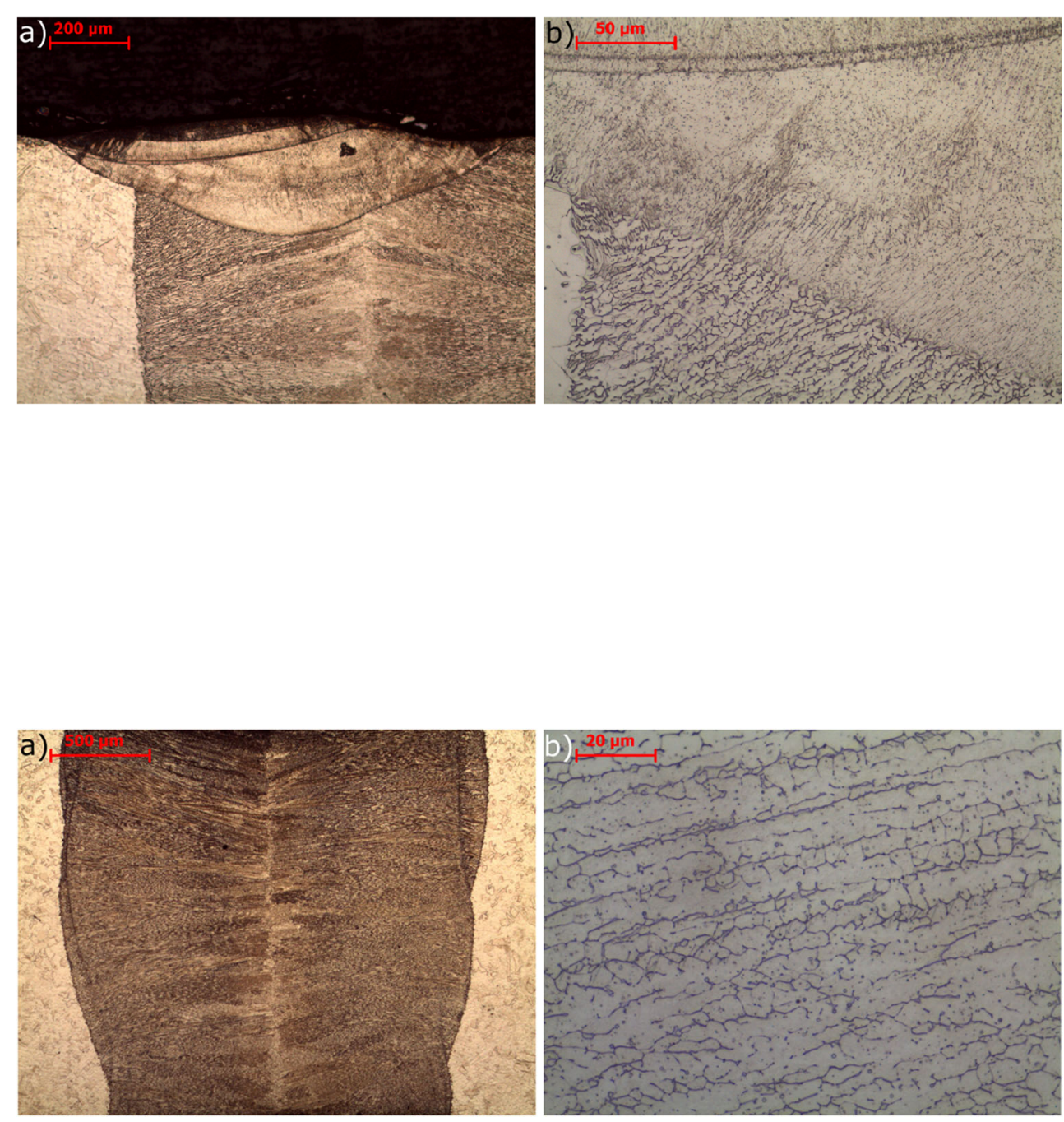

Fig. 9 Microstructure in the area of the second weld. a General view. b Detail view-austenite with lamellar ferrite

a)

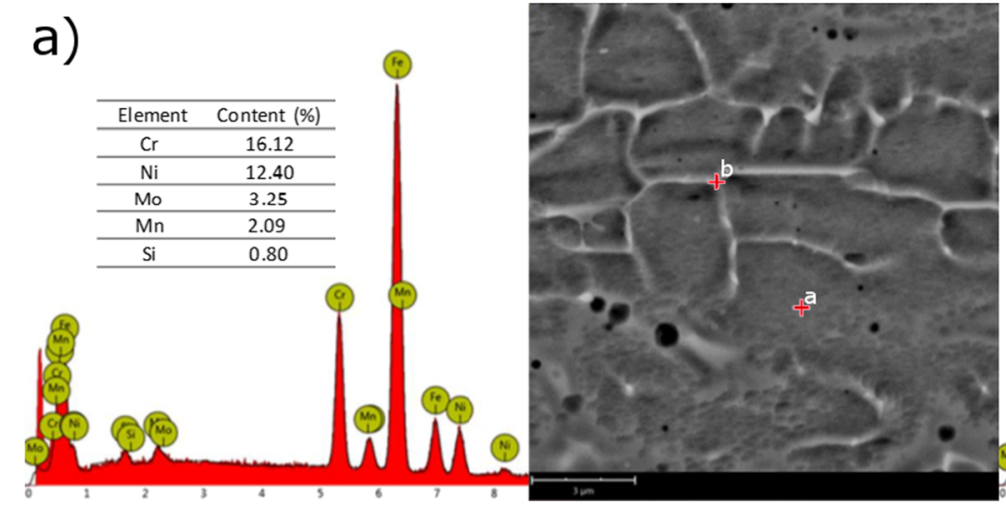

Fig. 10 Analysis of the chemical composition of the matrix (a) and precipitates (b)

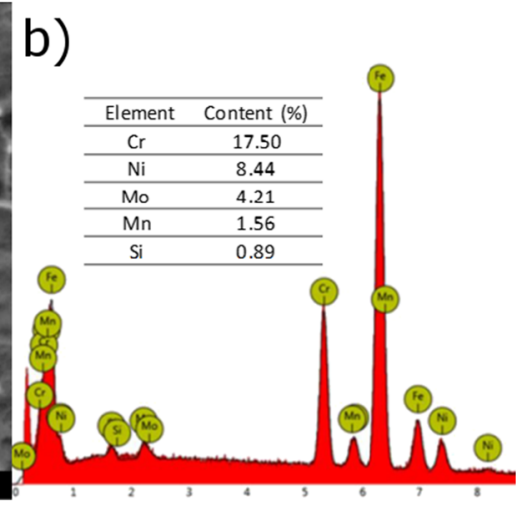


Fig. 11 a Design of the internal part of the container to be welded (PART 1). b General view

Fig. 12 a Design of the outer part of the container to be welded (PART 2). b General view
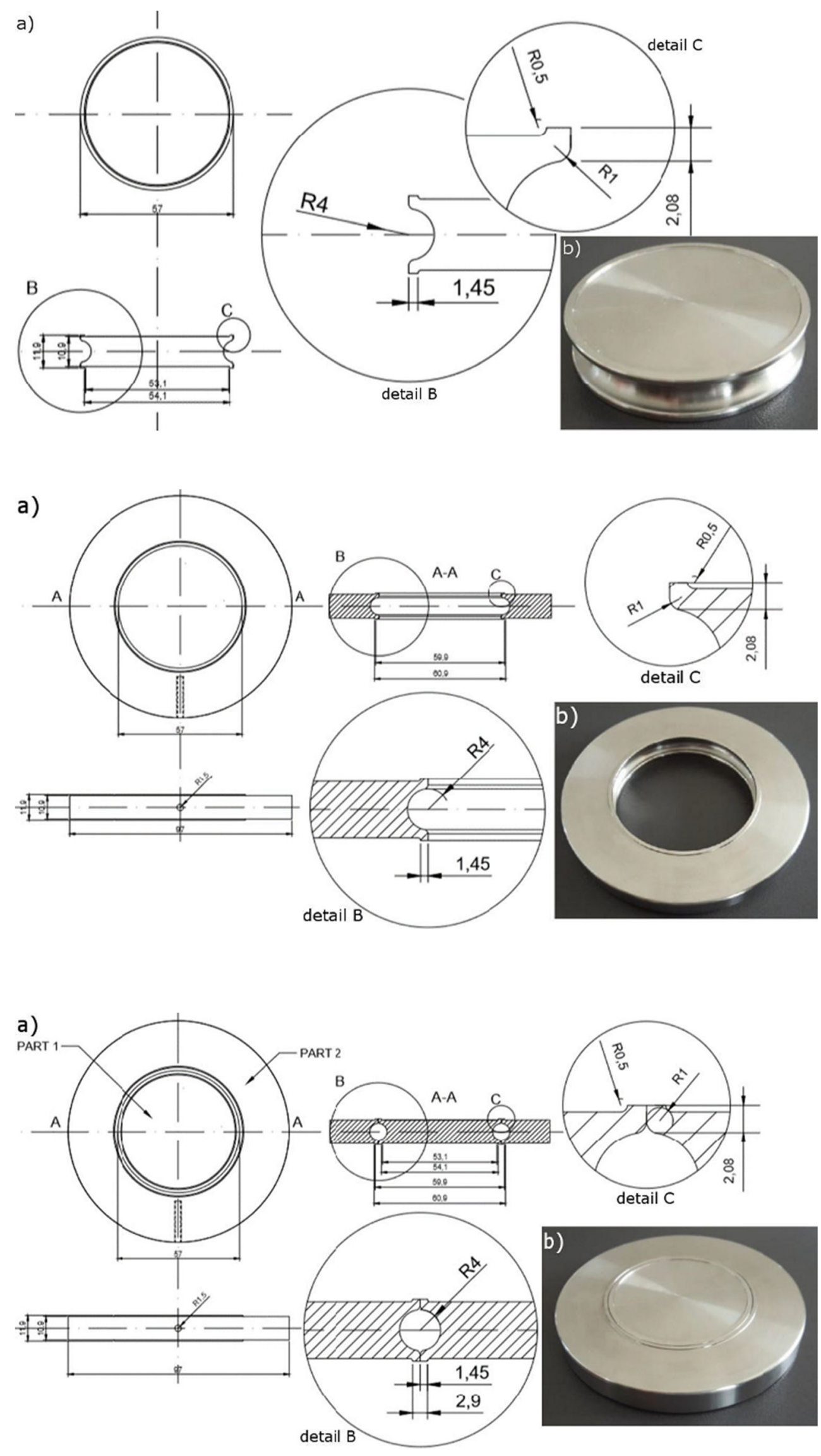

Fig. 13 a Design of parts arrangement during welding the container. b General view 
(i.e., ferrite stabilizers) proves that $\delta$-ferrite precipitation occurred at the cell borders, confirming Wang et al.'s [46] study.

The hardness of the weld was 140-160 HV3 and in the other zones was 170-200 HV3 and does not exceed the maximum values provided for in the standard for the base material (Table 2, $217 \mathrm{HBW} \approx 228 \mathrm{HV}$ acc. to ISO 18265). In the static tensile tests, the material cracked in the base material at the maximum applied loads $\left(\mathrm{F}_{\mathrm{m}}\right) 16.5$ and $17.5 \mathrm{kN}$, resulting in tensile strength $\left(R_{\mathrm{m}}\right) 687$ and $729 \mathrm{MPa}$. The high values far exceed the minimum requirements for the base material (Table 2). The elongation of both samples was $20 \%$ and no cracks were found. The bending angle in the static bending test for two samples was $180^{\circ}$, which means that the required plasticity of the joint was obtained.

\subsection{Examination a container prototype}

The container has been welded in two parts that were not made to the final shape. The inner part (PART 1) has a shape similar to the guide roller. The outer part (PART 2) has a diameter of $97 \mathrm{~mm}$, while the maximum diameter of the container is $70 \mathrm{~mm}$. In this part, a hole has also been drilled, whose task is to allow gases to escape during welding and later to fill the container with ferrofluid. The joint was cleaned and degreased before welding.
The surfaces of the to-be-welded parts were placed exactly and evenly, aligned with each other "by press," so that it was possible to put one part inside the other closely. Figures 11 and 12 show an overview and design of the parts to be welded. Figure 13 shows the design and general view of the container prepared for welding.

The technical drawing of the container is shown in Fig. $14 \mathrm{a}$, and the general view of the welded container is shown in Fig. 14b. The adaptation of the welding technology of the longitudinal weld to the circumferential weld required correction at the end of the weld. For this purpose, the known approach of reducing the power was used, described, e.g., by Jokisch et al. [47]. A circular, symmetrical weld without undercuts, pores, and cracks is visible. This means a successful welding process. However, this shape makes it possible to place it in the satellite structure. The final stage is machining to achieve the final dimensions (Fig. 14c), i.e., the outer diameter of the container to be reduced from 97 to $70 \mathrm{~mm}$ The center was removed in order to create a place for electromagnets, and the weld reinforcement was removed, such that an even and smooth surface of all external walls of the container was obtained.

The inner wall of the container is $1.5 \mathrm{~mm}$ thick, while the outer wall $2.5 \mathrm{~mm}$. This is because in the outer wall of
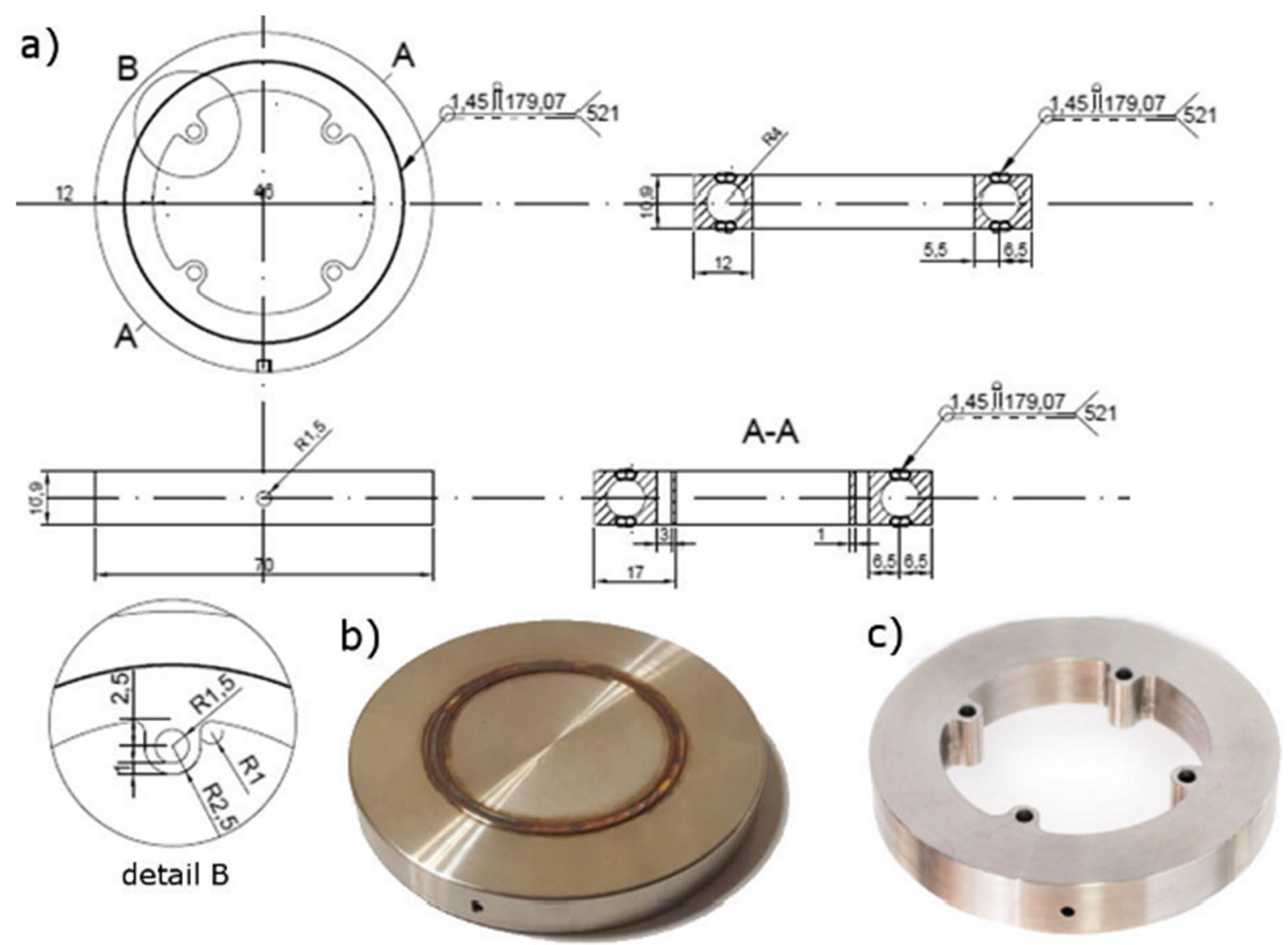

Fig. 14 a Container design. b Welded container. $\mathbf{c}$ The finished container 
the container there is a threaded hole with a diameter of 3 $\mathrm{mm}$, in which a screw will be screwed to permanently close the container. The wall has been thickened to increase the thread length of the screw sealing the hole. This increases the reliability of the container closure.

In order to check the container for leaks, a test was performed using a hose containing air at $0.8 \mathrm{MPa}$ pressure connected to a M3 threaded hole left in the test container placed underwater (Fig. 15a). The occurrence of two indications was tested: bubbles rising or a pressure drop visible on the pressure gauge. The set pressure of $0.8 \mathrm{MPa}$ was the result of an experimental finding of the highest possible pressure value that could affect the container walls during the fight when the ferrofluid has to counteract the force coming from the difference in the thermal expansion coefficients of the steel and the fluid. The only air bubbles detected were associated with a lack of integrity of the threaded hole M3. The welded joint was tight.

Because the container is to be within the satellite, it will not be directly exposed to vacuum of space and the sun's rays will not reach the surface of the container directly and low temperatures will be increased by the heat resulting from the operation of the satellite's electronic systems. As a result of this environment, the temperatures acting on the container will not fluctuate between -170 and $110^{\circ} \mathrm{C}$, but within -50 to $80^{\circ} \mathrm{C}$. To test whether the container can cope with these extreme conditions, it was placed in a vacuum chamber (Fig. 15b) and then heated three times to $80^{\circ} \mathrm{C}$ for $1 \mathrm{~h}$, and after a certain time, cooled to $-50^{\circ} \mathrm{C}$ three times for $1 \mathrm{~h}$. This cycling in a vacuum $10^{-3} \mathrm{~Pa}$ showed no effect on the required strength of the container.

In the electronic components, as they are heated their resistance increases and, by Ohm's law, the resistance causes heating. In particular, this applies to coils, and in the absence of control of maximum temperature, this may lead to device failure. To test the influence of the ferrofluid container on this, it was tested during operation in a vacuum using a thermal imaging camera. The maximum temperatures (Fig. 15b) in the structure that resulted from the operation of the device did not exceed $40^{\circ} \mathrm{C}$. Coils had the highest temperatures and the container was relatively cool. This is probably the result of isolating the coils from the rest of the structure using a plastic, polyamide. The container, despite its thermal conductivity, does not heat up, because the current cables are isolated.

The rocket that launches the satellite into space is subjected to vibrations of a certain amplitude for a period of several dozen seconds. In order to check the structure's resistance to
Fig. 15 a Underwater leak test. b Temperature testing during system operation in a vacuum chamber. c Vibration test results with general view of system mounted on a laboratory shaker
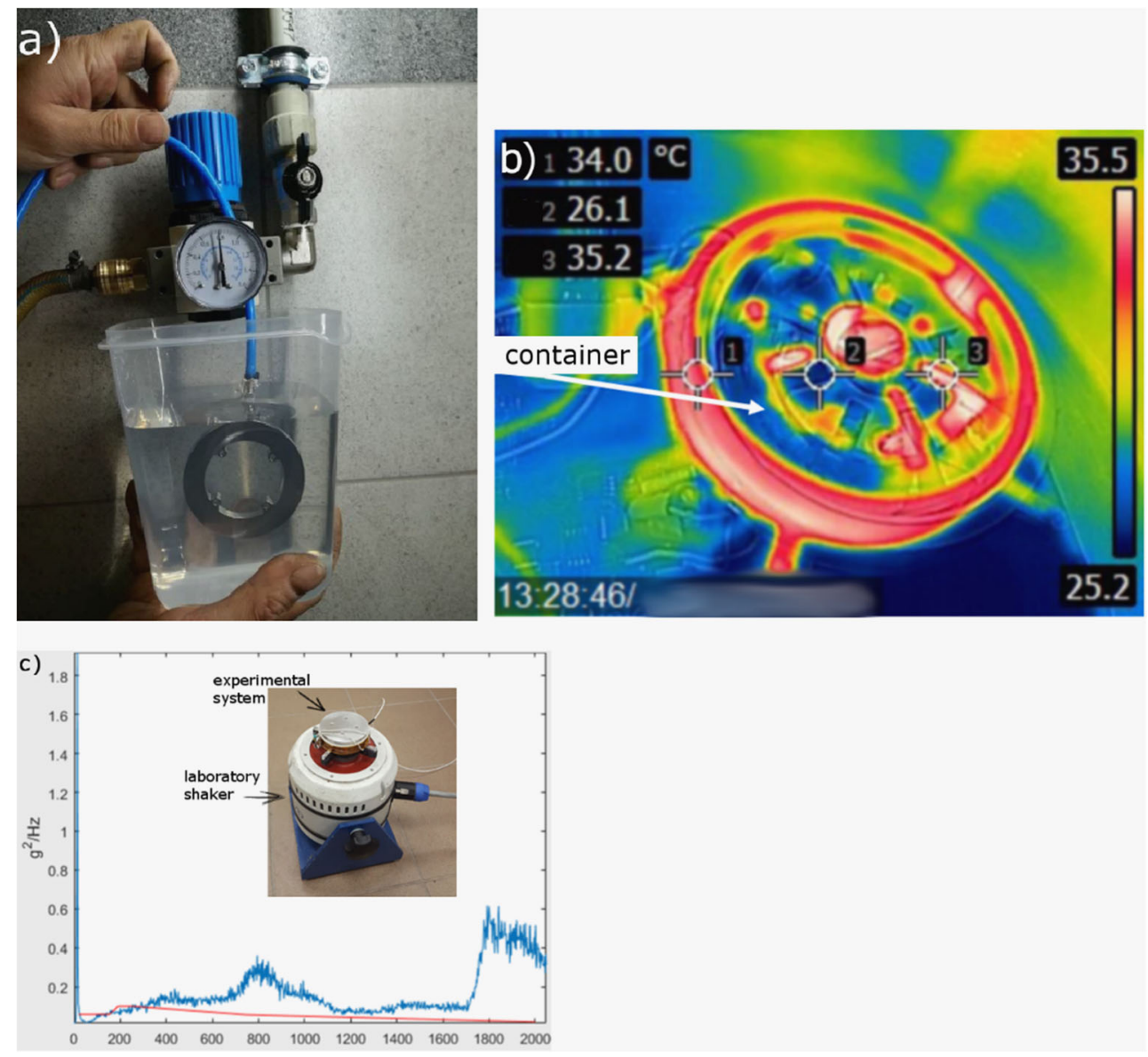
overload and whether the connected elements do not fall into resonance, vibration tests were carried out on a laboratory shaker. The maximum vibration amplitude during the tests was the maximum amplitude that may occur during the launch of the rocket (Fig. 15c). The container did not suffer any damage.

\section{Conclusions}

(1) The technology developed for welding a container intended for use in space is appropriate. The welds made are symmetrical, tight, and do not have welding defects or incompatibilities that may adversely affect their performance.

(2) An important point that should be noted when welding containers with a very small volume is the takeoff of gases. At the end of the last weld, if the gas does not have an outlet, it could enter the liquid metal forming pores.

(3) When welding AISI 316L stainless steel, the weld structure is not fully austenitic. If an important result of the welding is to obtain a weld with minimal magnetic properties, the welding process and material described in this paper are sufficient.

(4) Despite the spacing of welded joints from each other at 7-mm distance, their axial arrangement can lead to partial remelting of the first weld when making the second weld. For a $316 \mathrm{~L}$ steel container, this has no negative effect on the joint.

(5) Compliance with flywheel design and manufacturing requirements will enable the launch of a research satellite into orbit with such a wheel.

Funding Research was carried out as part of the KRAKSat project. Test joint testing was supported by the Polish Ministry of Science and Higher Education, Poland, in AGH University of Science and Technology, Poland, contract no. 16.16.110.663.

Open Access This article is licensed under a Creative Commons Attribution 4.0 International License, which permits use, sharing, adaptation, distribution and reproduction in any medium or format, as long as you give appropriate credit to the original author(s) and the source, provide a link to the Creative Commons licence, and indicate if changes were made. The images or other third party material in this article are included in the article's Creative Commons licence, unless indicated otherwise in a credit line to the material. If material is not included in the article's Creative Commons licence and your intended use is not permitted by statutory regulation or exceeds the permitted use, you will need to obtain permission directly from the copyright holder. To view a copy of this licence, visit http://creativecommons.org/licenses/by/4.0/.

\section{References}

1. Ali AA, Hegaze MM, Elrodesly AS (2019) Maximizing the onboard capability of the spacecraft attitude control system based on optimal use of reaction wheels. J Eur Syst Autom 52:397-407. https://doi.org/10.18280/jesa.520410

2. Ma KB, Zhang Y, Postrekhin Y, Chu W-K (2003) HTS bearings for space applications: reaction wheel with low power consumption for mini-satellites. IEEE T Appl Supercon 13:2275-2278. https:// doi.org/10.1109/TASC.2003.813064

3. Dong W, Li L, Tan L, Kong L, Yang H (2017) Flywheel microvibration characters of a high resolution optical satellite. J Vibroeng 19:3981-3993. https://doi.org/10.21595/jve.2017.17626

4. Mahdi MC (2018) Attitude stabilization for CubeSat: concepts and technology, 1st edn. Cambridge Scholars Publishing

5. Zhang Y, Postrekhin Y, Ma KB, Chu W-K (2002) Reaction wheel with HTS bearings for mini-satellite attitude control. Supercond Sci Technol 15:823-825. https://doi.org/10.1088/0953-2048/15/5/336

6. https://www.kraksat.pl/space. Accessed 17 July 2020.

7. Standard materials and processes requirements for spacecraft. NASA Technical Standard NASA-STD-6016.

8. Ogura T, Ichikawa S, Saida K (2018) Numerical analysis on solidification cracking susceptibility of type 316 stainless steel considering solidification mode and morphology computer simulation of hot cracking by solidification/segregation models. Weld Int 32: 445-452. https://doi.org/10.1080/09507116.2017.1346862

9. Kadoi K, Fujinaga A, Yamamoto M, Shinozaki K (2013) The effect of welding conditions on solidification cracking susceptibility of type $310 \mathrm{~S}$ stainless steel during laser welding using an in-situ observation technique. Weld World 57:383-390. https://doi.org/10. 1007/s40194-013-0023-9

10. Bansod AV, Patil AP (2017) Effect of welding processes on microstructure, mechanical properties, and corrosion behavior of lownickel austenitic stainless steels. Metallogr Microstruct Anal 6: 304-314. https://doi.org/10.1007/s13632-017-0368-3

11. Jażdżewska M, Majkowska-Marzec B (2017) Hydroxyapatite deposition on the laser modified Ti13Nb13Zr alloy. Adv Mater Sci 17:5-13. https://doi.org/10.1515/adms-2017-0017

12. Musztyfaga-Staszuk M, Gawlińska-Nęcek K, Janicki D, Panek P (2020) Laser-assisted copper oxidation. Arch Metall Mater 65:767770. https://doi.org/10.24425/amm.2020.132818

13. Jażdżewska $\mathrm{M}(2020)$ Effects of $\mathrm{CO}_{2}$ and $\mathrm{Nd}$ :YAG laser remelting of the Ti6Al4V alloy on the surface quality and residual stresses. Adv Mater Sci 20:82-90

14. He H, Forouzan F, Volpp J, Robertson SM, Vuorinen E (2021) Microstructure and mechanical properties of laser-welded DP steels used in the automotive industry. Materials 14:456. https://doi.org/ 10.3390/ma14020456

15. Robertson SM, Frostevarg J, Ramasamy A, Kalfsbeek B, Volpp J, Kaplan AFH (2020) Microstructures of high-strength steel welding consumables from directed thermal cycles by shaped laser pulses. Int J Adv Manuf Technol 109:2653-2662. https://doi.org/10.1007/ s00170-020-05749-1

16. Riofrío PG, Ferreira JAM, Capela CA (2021) Imperfections and modelling of the weld bead profile of laser butt joints in HSLA steel thin plate. Metals 11:151. https://doi.org/10.3390/ met11010151

17. Riofrío PG, Capela CA, Ferreira JA, Ramalho A (2020) Interactions of the process parameters and mechanical properties of laser butt welds in thin high strength low alloy steel plates. P I mech eng L-J Mat 234:665-680. https://doi.org/10.1177/ 1464420720910442

18. Giudice F, Sili A (2021) Weld metal microstructure prediction in laser beam welding of austenitic stainless steel. Appl Sci 11:1463. https://doi.org/10.3390/app11041463 
19. Landowski M, Świerczyńska A, Rogalski G, Fydrych D (2020) Autogenous fiber laser welding of 316L austenitic and 2304 lean duplex stainless steels. Materials 13:2930. https://doi.org/10.3390/ ma13132930

20. Lisiecki A, Kurc-Lisiecka A (2018) Automated laser welding of AISI 304 stainless steel by disk laser. Arch Metall Mater 63: 1663-1672. https://doi.org/10.24425/amm.2018.125091

21. Oladimeji OO, Taban E (2016) Trend and innovations in laser beam welding of wrought aluminum alloys. Weld World 60:415-457. https://doi.org/10.1007/s40194-016-0317-9

22. Kumar P, Sinha AN (2019) Effect of heat input in pulsed Nd:YAG laser welding of titanium alloy (Ti6Al4V) on microstructure and mechanical properties. Weld World 63:673-689. https://doi.org/10. 1007/s40194-018-00694-w

23. Jurado M, Altamirano G, Acevedo J, Aguirre A (2019) Microstructural characterization of the laser welding in a nickel based superalloy. MRS Adv 63:3463-3473. https://doi.org/10. 1557/adv.2019.421

24. Acherjee B (2021) Laser transmission welding of dissimilar plastics: 3-D FE modeling and experimental validation. Weld World. https://doi.org/10.1007/s40194-021-01079-2

25. Jaeschke P, Wippo V, Suttmann O, Overmeyer L (2015) Advanced laser welding of high-performance thermoplastic composites. J Laser Appl 27:S29004

26. Guo W, Li L, Dong S, Crowther D, Thompson A (2017) Comparison of microstructure and mechanical properties of ultranarrow gap laser and gas-metal-arc welded S960 high strength steel. Opt Lasers Eng 91:1-15. https://doi.org/10.1016/j. optlaseng.2016.11.011

27. Bakir N, Pavlov V, Zavjalov S, Volvenko S, Gumenyuk A, Rethmeier M (2019) Development of a novel optical measurement technique to investigate the hot cracking susceptibility during laser beam welding. Weld World 63:435-441. https://doi.org/10.1007/ s40194-018-0665-8

28. Gook S, Üstündağ Ö, Gumenyuk A, Rethmeier M (2020) Avoidance of end crater imperfections at high-power laser beam welding of closed circumferential welds. Weld World 64:407-417. https://doi.org/10.1007/s40194-019-00841-x

29. Sajek A (2019) Application of FEM simulation method in area of the dynamics of cooling AHSS steel with a complex hybrid welding process. Weld World 63:1065-1073. https://doi.org/10.1007/ s40194-019-00718-z

30. Sajek A (2020) Welding thermal cycles of joints made of S1100QL steel by saw and hybrid plasma-Mag processes. Adv Mater Sci 20: 75-86. https://doi.org/10.2478/adms-2020-0023

31. Faraji AH, Goodarzi M, Seyedein SH, Maletta C (2016) Effects of welding parameters on weld pool characteristics and shape in hybrid laser-TIG welding of AA6082 aluminum alloy: numerical and experimental studies. Weld World 60:137-151. https://doi.org/10. 1007/s40194-015-0278-4

32. Jiang W, Zhang Y, Woo W (2012) Using heat sink technology to decrease residual stress in 316L stainless steel welding joint: Finite element simulation. Int J Press Vessel Pip 92:56-62. https://doi.org/ 10.1016/j.ijpvp.2012.01.002

33. Chen XH, Lu J, Lu L, Lu K (2005) Tensile properties of a nanocrystalline 316L austenitic stainless steel. Scr Mater 52:1039-1044. https://doi.org/10.1016/j.scriptamat.2005.01.023
34. Paffumi E, Nilsson K-F, Taylor N, Hurst R, Bache M (2005) Crack initiation, propagation, and arrest in $316 \mathrm{~L}$ model pipe components under thermal fatigue. J ASTM Int 5:1-18. https://doi.org/10.1520/ JAI12035

35. Paffumi E, Nilsson K-F, Taylor N (2008) Thermal fatigue cyclicdown shocks on $316 \mathrm{~L}$ model pipe components. Proceedings of the ASME 2008 Pressure Vessels and Piping Conference. Volume 3: Design and Analysis, pp 665-673. https://doi.org/10.1115/ PVP2008-61853

36. Korinko PS, Malene SH (2001) Considerations for the weldability of types 304L and 316L stainless steel. Pract Fail Anal 1:61-68. https://doi.org/10.1007/BF02715336

37. Mendez PF, Eagar TW (2001) Welding processes for aeronautics. Adv Mater Process 159:39-43

38. Kik T (2020) Heat source models in numerical simulations of laser welding. Materials 13:2653. https://doi.org/10.3390/ma13112653

39. Hernández-Trujillo SL, Lopez-Morelos VH, García-Rentería MA, García-Hernández R, Ruiz A, Curiel-López FF (2021) Microstructure and fatigue behavior of 2205/316L stainless steel dissimilar welded joints. Metals 11:93. https://doi.org/10.3390/ met11010093

40. Pańcikiewicz K, Świerczyńska A, Hućko P, Tumidajewicz M (2020) Laser dissimilar welding of AISI 430F and AISI 304 stainless steels. Materials 13:4540. https://doi.org/10.3390/ma13204540

41. Tokita S, Kadoi K, Kanno Y, Inoue H (2020) Microstructural evolution and solidification cracking susceptibility of grain boundary engineered fully austenitic stainless steel. Weld World 64:593-600. https://doi.org/10.1007/s40194-020-00865-8

42. Hochanadel JE, Patterson T, Lippold JC, Panton B, Johnson MQ, Tung DC (2021) Influence of focus and deflection when comparing electron beam welds to laser welds at varying parameters in $304 \mathrm{SS}$. Weld World. https://doi.org/10.1007/s40194-020-01046-3

43. Moteshakker A, Danaee I (2016) Microstructure and corrosion resistance of dissimilar weld-joints between duplex stainless steel 2205 and austenitic stainless steel 316L. J Mater Sci Technol 32: 282-290. https://doi.org/10.1016/j.jmst.2015.11.021

44. Chen L, Yang T, Zhuang Y, Chen W (2021) The multi-objective optimization modelling for properties of 301 stainless steel welding joints in ultra-narrow gap laser welding. Weld World 65:87-93. https://doi.org/10.1007/s40194-021-01068-5

45. Tuz L (2016) Microstructure evaluation of laser-welded 600 nickel alloy. Metall Foundry Eng 42:233-238. https://doi.org/10.7494/ mafe.2016.42.4.233

46. Wang Q, Ren Y, Yao C, Yang K, Misra RDK (2015) Residual ferrite and relationship between composition and microstructure in high-nitrogen austenitic stainless steels. Metall Mater Trans A 46:5537-5542. https://doi.org/10.1007/s11661-015-3160-5

47. Jokisch T, Marko A, Gook S, Üstündag Ö, Gumenyuk A, Rethmeier M (2019) Laser welding of SLM-manufactured tubes made of IN625 and IN718. Materials 12:2967. https://doi.org/10. $3390 / \mathrm{ma} 1218296$

Publisher's note Springer Nature remains neutral with regard to jurisdictional claims in published maps and institutional affiliations. 